\title{
ANALISIS TENTANG PARLIAMENTARY THRESHOLD DAN CALON PERSEORANGAN BERDASARKAN UNDANG-UNDANG NOMOR 10 TAHUN 2016 DALAM PERSPEKTIF DEMOKRASI DAN PRINSIP CHECK AND BALLANCES
}

\author{
Surya Darma Kardeli \\ Fakultas Hukum Universitas Bung Hatta \\ Jl. Sumatera Ulak Karang Padang, Sumatera Barat \\ E-mail : suryakardeli@gmail.com
}

\begin{abstract}
The application of the parliamentary threshold in the conduct of the elections is still a problem for political parties. Determination of the limits of the requirements to be met by political parties to be able to register candidates as set forth in the provisions of article 40 paragraph (1) of Act No. 201610 years about the election of the Governor, Governor and Mayor, was by fulfilling the most gains of at least $20 \%$ of the total area of the House of representatives seats or $25 \%$ of the accumulated gains of legitimate votes in the general election of members of the House of representatives in the Regions concerned. In addition, the mechanism of elections nowadays also provides the opportunity for individual candidates to be able to advance in the implementation of the elections. This is a real form of the implementation of the people's democracy, due to the demands of the people to get the leaders of his country who have the attitude that aspirational, competent, legitimate and not just think of the interests of political parties. But in fact, the spirit of democracy through mechanisms of individual candidates much have obstacles, one of which is to embody the principle of checks and balances in the Organization of the functions of Government. Based on the above description, then the legal research is trying to give the explanation with regard to whether the reason that the application of parliamentary threshold in the law No. 10 The year 2016 could hinder the implementation of democracy and how are the dynamics of the working relationship between parliament and the prospective head of the area of an individual who is not capable of embodying the principle of checks and balances. This study derives the conclusion that implementation the parliamentary threshold in the conduct of the elections could hinder the implementation of democracy because it is contrary to the laws and regulations and may also harm the justice the coveted by society and are protected by the Constitution of 1945. With regard to the inability to realize the principle of checks and balances in the relationship between Government function of organizing local and regional head of individual candidates that caused a political attitude which parliament does not provide support politics to the head area of an individual.
\end{abstract}

Keywords: Parliamentary Threshold, Individual Candidates, Democracy, Checks and Balances

Abstrak
Penerapan parliamentary threshold dalam pelaksanaan pilkada masih menjadi permasalahan
bagi partai politik. Penentuan batasan persyaratan yang harus dipenuhi oleh partai politik
untuk dapat mendaftarkan calonnya sebagaimana yang termaktub di dalam ketentuan Pasal 40
Ayat (1) Undang-Undang Nomor 10 Tahun 2016 tentang Pemilihan Gubernur, Bupati dan 
Walikota, adalah dengan memenuhi perolehan paling paling sedikit $20 \%$ dari jumlah kursi Dewan Perwakilan Rakyat Daerah atau 25\% dari akumulasi perolehan suara sah dalam pemilihan umum anggota Dewan Perwakilan Rakyat Daerah di daerah yang bersangkutan. Selain itu, mekanisme pilkada dewasa ini juga memberikan kesempatan bagi calon perseorangan untuk dapat maju dalam pelaksanaan pilkada. Hal ini merupakan bentuk nyata dari pelaksanaan demokrasi rakyat, karena adanya tuntutan dari rakyat untuk mendapatkan calon pemimpin daerahnya yang memiliki sikap yang aspiratif, kompeten, legitimate serta tidak hanya memikirkan kepentingan partai politik. Namun kenyataannya semangat demokrasi melalui mekanisme calon perseorangan ini banyak memiliki kendala, salah satunya yaitu untuk mewujudkan prinsip check and balances dalam penyelenggaraan fungsi pemerintahan. Berdasarkan uraian di atas, maka penelitian hukum ini mencoba memberikan uraian berkenaan dengan apakah yang menjadi alasan bahwa penerapan parliamentary threshold di dalam Undang-Undang Nomor 10 Tahun 2016 dapat menghambat pelaksanaan demokrasi dan bagaimanakah dinamika hubungan kerja antara DPRD dan calon kepala daerah dari perseorangan yang tidak mampu mewujudkan prinsip check and balances. Penelitian ini memperoleh kesimpulan bahwa penerpan parliamentary threshold dalam pelaksanaan pilkada dapat menghambat pelaksanaan demokrasi karena hal ini bertentangan dengan peraturan perundang-undangan dan juga dapat mencederai keadilan yang didambakan oleh masyarakat dan dilindungi oleh UUD 1945. Berkenaan dengan ketidakmampuan mewujudkan prinsip check and balances dalam hubungan penyelenggaraan fungsi pemerintahan antara DPRD dan calon kepala daerah dari perseorangan yaitu disebabkan sikap politik DPRD yang tidak memberikan dukungan politik kepada kepala daerah dari perseorangan.

\section{Kata Kunci: Parliamentary Threshold, Calon Perseorangan, Demokrasi, Check and Balances}

\section{A. PENDAHULUAN}

Amandemen terhadap Undang-Undang Dasar Negara Kesatuan Republik Indonesia Tahun 1945 telah membawa perubahan besar pada sistem ketatanegaraan. Salah satu perubahan itu terkait dengan pengisian jabatan Kepala Daerah sebagaimana yang termaktub di dalam Pasal 18 Ayat (4) UUD 1945 bahwa, "Gubernur, Bupati, dan Walikota masing-masing sebagai kepala pemerintahan daerah provinsi, kabupaten, dan kota dipilih secara demokratis".

Frase "dipilih secara demokratis" bersifat luwes, sehingga mencakup pengertian Kepala Daerah langsung oleh rakyat ataupun oleh DPRD seperti yang pada umunya pernah dipraktekkan di daerah-daerah berdasarkan ketentuan perundang-undangan yang berlaku. ${ }^{2}$ Ketentuan ini memberi peluang untuk diinterpretasikan bahwa pemilihan Kepala Daerah harus dilakukan secara demokratis. Sekiranya klausul "dipilih secara demokratis" diparalelkan dengan proses pemilihan Presiden dan Wakil Presiden di tingkat nasional, maka di daerah pun dapat dilakukan pemilihan Kepala Daerah secara langsung. Dengan adanya

\footnotetext{
${ }^{1}$ Undang-Undang Dasar Negara Republik Indonesia Tahun 1945, Sekretariat Jenderal MPR RI, 2011, hal 134 .

2 Jimly Asshiddiqie, Konsolidasi Naskah UUD 1945 Setelah Perubahan Keempat, Pusat Studi Hukum Tata Negara UI, 2002, hlm, 22.
} 
perubahan proses pengisian jabatan Presiden dan Wakil Presiden, proses pemilihan Kepala Daerah dengan sistem perwakilan menjadi kehilangan relevansinya. ${ }^{3}$

Alasan yuridis lain yang mengharuskan kepala daerah dipilih secara langsung adalah seperti yang termaktub di dalam Pasal 317 Ayat (1) huruf d dan Pasal 366 Ayat (1) huruf d, Undang-Undang Nomor 17 Tahun 2014 tentang Majelis Permusyawaratan Rakyat, Dewan Perwakilan Rakyat, Dewan Perwakilan Daerah, dan Dewan Perwakilan Rakyat Daerah. Inti dari substansi kedua pasal tersebut menyatakan bahwa DPRD mempunyai wewenang dan tugas yaitu mengusulkan pengangkatan dan pemberhentian kepala daerah, bukan untuk memilih kepala daerah.

Selain itu, berkenaan dengan pemilihan kepala daerah secara langsung juga tersirat di dalam penjelasan atas Undang-Undang Nomor 23 Tahun 2014 jo Undang-Undang Nomor 9 Tahun 2015 tentang Pemerintahan Daerah, yang menyatakan bahwa penyelenggaraan pemerintahan daerah dilaksanakan oleh DPRD dan kepala daerah, DPRD dan kepala daerah berkedudukan sebagai unsur penyelenggara pemerintahan yang diberi mandat oleh rakyat untuk melaksanakan Urusan Pemerintahan yang diserahkan kepada Daerah, dengan demikian maka DPRD dan kepala daerah berkedudukan sebagai mitra sejajar yang mempunyai fungsi yang berbeda.

Menurut S.H. Sarundajang, perubahan-perubahan ketentuan mengenai pemilihan kepala daerah dan wakil kepala daerah itu merupakan konsekuensi dari tuntutan demokratisasi yang tentunya akan berpengaruh pada kegiatan pemerintahan di tingkat lokal (local government). Diakui bahwa sejak lama rakyat telah menghendaki pilkada dilakukan secara langsung. ${ }^{4}$ Hal senada juga diungkapkan oleh I Gde Pantja Astawa, yang menyatakan bahwa otonomi daerah terkait erat dengan demokrasi. Konsekuensinya, harus ada tata cara dan mekanisme pengisian jabatan-jabatan secara demokratis, terutama pada jabatan-jabatan politik. ${ }^{5}$

Dalam perspektif desentralisasi dan demokrasi prosedural, sistem Pilkada merupakan sebuah inovasi yang bermakna dalam proses konsolidasi demokrasi di aras lokal. Setidaknya, sistem pilkada memiliki sejumlah keunggulan dibandingkan dengan sistem rekrutmen politik yang ditawarkan oleh model sentralistik menurut Undang-Undang Nomor 5 Tahun 1974 yaitu kepala daerah dipilih oleh DPRD, dan model demokrasi perwakilan yang diretas oleh Undang-Undang Nomor 22 Tahun 1999 yaitu kepala daerah sepenuhnya menjadi kepala otonom yang dipilih dan bertanggung jawab pada DPRD.

Pelaksanaan nyata kehendak rakyat untuk melakukan pilkada langsung termaktub dalam Pasal 1 Ayat (1) Undang-Undang Nomor 10 Tahun 2016 tentang Pemilihan Gubernur, Bupati dan Walikota, yang menyatakan "Pemilihan Gubernur dan Wakil Gubernur, Bupati dan Wakil Bupati serta Walikota dan Wakil Walikota yang selanjutnya disebut Pemilihan adalah

${ }^{3}$ Suharizal, Pemilukada (Regulasi, Dinamika, dan Konsep Mendatang), PT Raja Grafindo Persada, Jakarta, 2012, hlm, 2.

${ }^{4}$ S.H. Sarundajang, Pilkada Langsung, Problema dan Prospek, Katahasta Pustaka, 2005, hlm, 2-3.

${ }^{5}$ I Gde Pantja Astawa, Problematika Hukum Otonomi Daerah di Indonesia, Alumni, Bandung, 2008, hlm, 21. 
pelaksanaan kedaulatan rakyat di wilayah provinsi dan kabupaten/kota untuk memilih Gubernur dan Wakil Gubernur, Bupati dan Wakil Bupati serta Walikota dan Wakil Walikota secara langsung dan demokratis". Sedangkan Menurut Pasal 1 Ayat (3) dan Ayat (4), calon Kepala Daerah adalah peserta Pemilihan yang diusulkan oleh partai politik, gabungan partai politik, atau perseorangan yang didaftarkan atau mendaftar di Komisi Pemilihan Umum.

Berdasarkan pembahasan di atas, Undang-Undang Nomor 10 Tahun 2016, sangat menginginkan terwujudnya demokratisasi dalam pemerintahan dan masyarakat daerah. Namun cita-cita demokratisasi tersebut sepertinya akan mendapat hambatan dari penerapan parliamentary threshold, sebagaimana yang termaktub di dalam Pasal 40 Ayat (1) yang menyatakan "Partai Politik atau gabungan partai politik dapat mendaftarkan pasangan calon jika telah memenuhi persyaratan perolehan paling sedikit $20 \%$ dari jumlah kursi Dewan Perwakilan Rakyat Daerah atau 25\% dari akumulasi perolehan suara sah dalam pemilihan umum anggota Dewan Perwakilan Rakyat Daerah di daerah yang bersangkutan”. Ketentuan Pasal 40 Ayat (1) ini juga bertentang dengan Undang-Undang Nomor 2 Tahun 2008 jo Undang-Undang Nomor 2 Tahun 2011 tentang Partai Politik, di dalam Pasal 12 huruf a menjelaskan bahwa, "Partai Politik berhak memperoleh perlakuan yang sama, sederajat, dan adil dari negara".

Selain itu, berkenaan dengan dinamika hubungan kerja antara DPRD dan calon kepala daerah dari perseorangan menurut Pasal 41 Ayat (1) dan Ayat (2), yang memberikan kesempatan bagi calon kepala daerah dari perseorangan untuk dapat mengikuti pilkada langsung tanpa harus bergabung dengan partai politik atau gabungan partai politik. Pasal 41 Ayat (1) dan Ayat (2) merupakan pelaksanaan keinginan masyarakat yang dewasa ini semakin tidak percaya pada kinerja partai politik. Namun di sisi lain hal ini juga akan menghambat terlaksananya prinsip check and balances, kepala daerah dari perseorangan akan menghadapi permasalahan berkaitan dengan sikap politik DPRD yang tidak memberikan dukungan politik kepada kepala daerah tersebut.

Oleh karena itu, berkaitan dengan permasalahan di atas dalam penulisan hukum ini, penulis akan membahas mengenai analisis tentang Parliamentary Threshold dan calon perseorangan dalam perspektif demokrasi dan prinsip check and ballances berdasarkan Undang-Undang Nomor 10 Tahun 2016.

Berdasarkan latar belakang permasalahan yang telah diuraikan di atas, serta agar permasalahan yang akan diteliti menjadi lebih jelas dan penulisan hukum mencapai tujuan yang diinginkan, maka masalah pokok yang akan diteliti oleh penulis adalah:

1. Apakah alasan penerapan parliamentary threshold di dalam Undang-Undang Nomor 10 Tahun 2016 dapat menghambat pelaksanaan demokrasi?

2. Bagaimanakah dinamika hubungan kerja antara DPRD dan calon kepala daerah dari perseorangan yang tidak mampu mewujudkan prinsip check and ballances?

\section{B. PEMBAHASAN}




\section{Alasan Penerapan Parliamentary Threshold Di Dalam Undang-Undang Nomor 10 Tahun 2016 Dapat Menghambat Pelaksanaan Demokrasi.}

Inti dari demokrasi adalah kebebasan dan kemerdekaan. Kebebasan bermakna seorang warga negara berhak menentukan apa pilihannya, sedangkan kemerdekaan berarti ia mempunyai kewenangan penuh untuk berbuat tanpa tekanan dan intimidasi apapun. ${ }^{6}$ Pilkada secara langsung yang diinginkan oleh rakyat pada dasarnya ingin menguatkan dan memperbaiki kualitas demokrasi. Secara normatif, berdasarkan ukuran-ukuran demokrasi, pilkada langsung menawarkan sejumlah manfaat dan sekaligus harapan bagi pertumbuhan, pendalaman dan perluasan demokrasi lokal. Berikut ini merupakan manfaat dari pelaksanaan pilkada langsung:

a. Sistem demokrasi langsung melalui pilkada langsung akan membuka ruang partisipasi yang lebih luas bagi masyarakat dalam proses demokrasi dan menentukan kepemimpinan politik di tingkat lokal dibandingkan sistem demokrasi perwakilan yang lebih banyak meletakkan kuasa untuk menentukan rekrutmen politik di tangan segelintir orang di DPRD;

b. Dari sisi kompetisi politik, pilkada langsung memungkinkan munculnya secara lebih lebar preferensi kandidat-kandidat yang bersaing serta memungkinkan masingmasing kandidat berkompetisi dalam ruang yang lebih terbuka dibandingkan ketertutupan yang sering terjadi dalam demokrasi perwakilan. Pilkada langsung bisa memberikan sejumlah harapan pada upaya pembalikan "syndrome" dalam demokrasi perwakilan yang ditandai dengan model kompetisi yang tidak fair, seperti; praktik politik uang (money politics). ${ }^{7}$;

c. Sistem pemilihan langsung akan memberikan peluang bagi warga untuk mengaktualisasi hak-hak politiknya secara lebih baik tanpa harus direduksi oleh kepentingan-kepentingan elit politik;

d. Pilkada langsung memperbesar harapan untuk mendapatkan figur pemimpin yang aspiratif, kompeten, dan legitimate. Karena melalui pilkada langsung, kepala daerah yang terpilih lebih berorientasi pada warga dibandingkan pada segelintir elit di DPRD. Hal ini juga memberikan manfaat berkaitan dengan peningkatan kualitas tanggung jawab pemerintah daerah pada warganya yang pada akhirnya akan mendekatkan kepala daerah dengan masyarakat;

e. Kepala daerah yang terpilih melalui pilkada langsung akan memiliki legitimasi politik yang kuat sehingga akan terbangun perimbangan kekuatan (check and balances) di daerah antara kepala daerah dengan DPRD. Perimbangan kekuatan ini akan meminimalisasi penyalahgunaan kekuasaan seperti yang muncul dalam format politik yang monolitik.

${ }^{6}$ Hery Susanto dkk, Menggapai Demokrasi (Jejak Syaukani HR, Konflik Politik dan Memenangi Pilkada), Penerbit Republika, Jakarta, 2005, hlm, 63.

${ }_{7}^{7}$ Suharizal, Gagasan Pemilihan Kepala Daerah Langsung, dalam Reformasi Hukum, Fakultas Hukum Universitas Andalas, Padang, 2003, hlm, 89. 
Tujuan yang ingin dicapai di dalam pelaksanaan pilkada secara langsung salah satunya adalah untuk mendapatkan sosok pemimpin kepala daerah yang sesuai dengan keinginan masyarakatnya, namun dengan penerapan parliamentary threshold di dalam pelaksanaan pilkada membuat tujuan tersebut akan sulit terlaksana bahkan hal ini menimbulkan ketidakadilan bagi sejumlah partai politik.

Berdasarkan ketidakadilan ini pada tahun 2005 para pihak yang merasa dirugikan haknya atas penerapan parliamentary threshold mengajukan pengujian undang-undang ke Mahkamah Konstitusi (MK). Berdasarkan putusan MK Nomor 005/PUU-III/2005 tanggal 22 Maret 2005, yaitu permohonan pengujian Penjelasan Pasal 59 Ayat (1) Undang-Undang Nomor 32 Tahun 2004 tentang Pemerintahan Daerah terhadap UUD 1945. Para pemohon mendalilkan bahwa pemberlakuan Penjelasan Pasal 59 Ayat (1) UU Nomor 32 Tahun 2004 berpotensi menyebabkan tidak terselenggaranya pilkada yang demokratis, langsung, umum, bebas, rahasia, jujur, dan adil, dan terlebih lagi Penjelasan Pasal 59 Ayat (1) tersebut telah menghalangi hak konstitusional para pemohon baik secara pribadi warga negara Indonesia. lain: ${ }^{8}$

Beberapa alasan pemohon dalam mengajukan permohonan uji materil ke MK, antara

a. UU Nomor 32 Tahun 2004 khususnya pada Pasal 59 Ayat (1) dan Ayat (2) serta Penjelasan Pasal 59 Ayat (1), menurut para pemohon telah mengaburkan dan menghilangkan substansi dari batang tubuh Pasal 59 Ayat (1) dan (2). Substansi batang tubuh Pasal 59 Ayat (1) dan (2), mengatur bahwa yang boleh mengusulkan calon adalah partai politik atau gabungan partai politik yang memiliki sekurangkurangnya $15 \%$ dari jumlah kursi di DPRD atau 15\% dari akumulasi perolehan suara sah dalam pemilihan umum anggota DPRD di daerah yang bersangkutan. Apa yang diatur dalam batang tubuh pasal tersebut sebenarnya sudah sangat jelas, masalahnya timbul pada saat membaca Penjelasan Pasal 59 Ayat (1) yang menyatakan bahwa partai politik atau gabungan partai politik dalam ketentuan ini adalah partai politik atau gabungan partai politik yang memiliki kursi di DPRD.

b. Dengan adanya Penjelasan Pasal 59 Ayat (1) tersebut, itu berarti bahwa Pasal 59 Ayat (2) yang memberikan kesempatan kepada gabungan partai politik yang memiliki $15 \%$ akumulasi perolehan suara sah dalam pemilihan umum anggota DPRD di daerah yang bersangkutan sudah dianulir, karena yang dimungkinkan untuk mengusulkan pasangan calon dengan adanya Penjelasan Pasal 59 Ayat (1) tersebut hanyalah adalah partai politik atau gabungan partai politik yang memperoleh $15 \%$ dari jumlah kursi DPRD. Antara Pasal 59 Ayat (1) dan Ayat (2) diperhadapkan dengan Penjelasan Pasal 59 Ayat (1) terdapat Contradictio in Terminis, sehingga dengan demikian menjadikan Penjelasan Pasal 59 Ayat (1) cacat hukum. Seharusnya Pasal 59 Ayat (1) sudah tidak memerlukan penjelasan, karena sudah sangat jelas. hlm, 7-9.

\footnotetext{
${ }^{8}$ Dikutip dari Putusan Perkara No. 005/PUU-III/2005 tanggal 22 Maret 2005 Mahkamah Konstitusi,
} 
c. Pemohon berpendapat bahwa dalam Penjelasan Pasal 59 Ayat (1) bukan hanya sekedar penjelasan, tetapi adalah merupakan suatu regulasi baru yang seharusnya diletakkan dalam batang tubuh dan bukan dalam penjelasan.

d. UUD 1945 Pasal 18 Ayat (4) mengamanatkan bahwa, Pemilihan Gubernur, Bupati, dan Walikota masing-masing sebagai kepala Pemerintahan Daerah Provinsi, Kabupaten dan Kota dipilih secara demokratis. Hakikat dalam pasal tersebut "dipilih secara demokratis" bukan hanya pada pelaksanaan pemungutan suara dan perhitungan suara yang harus demoratis, tetapi juga harus ada jaminan pada saat penjaringan dan penetapan calon. Masyarakat perlu mendapatkan akses yang luas untuk berpartisipasi dalam mengusung pasangan calon atau untuk dicalonkan. Oleh sebab itu, pembatasan sebagaimana dimaksud Dalam Penjelasan Pasal 59 Ayat (1) tersebut sungguh-sungguh tidak mencerminkan asas demokrasi sebagaimana dimaksud dalam Pasal 18 Ayat (4) UUD 1945.

e. Para pemohon adalah sebagian dari Partai Pollitik Peserta Pemilu tahun 2004 di Provinsi Sulawesi Utara, baik yang memiliki anggota (kursi) DPRD namun tidak mencapai jumlah $15 \%$ kursi di DPRD, maupun partai politik yang tidak memiliki kursi di DPRD, jika dijumlahkan akumulasi perolehan suara sah pada Pemilu DPRD Provinsi Sulawesi Utara ternyata partai-partai politik tersebut, telah berhasil mengumpulkan $34,4 \%$ suara sah. Suara rakyat yang telah disalurkan lewat partaipartai politik tersebut seyogianya dihargai oleh UU Pemda dengan memberikan kesempatan kepada partai-partai politik tersebut, untuk dapat mengusulkan pasangan calon.

f. Memerhatikan syarat yang ditetapkan oleh Pasal 59 Ayat (2) UU Nomor 32 Tahun 2004 tentang Pemerintahan Daerah tersebut, bahwa yang boleh mendaftarkan pasangan calon adalah partai politik atau gabungan partai politik yang memiliki $15 \%$ kursi di DPRD atau 15\% akumulasi perolehan suara sah dalam Pemilu 2004, maka itu berarti secara matematis paling banyak hanya ada 6 pasangan calon yang dapat mendaftarkan diri $(100 \%: 15 \%=6$ pasangan calon). Jumlah 6 calon dalam suatu pilkada yang demokratis, adalah jumlah yang dianggap relatif sedikit, namun sudah dapat memberikan kesempatan yang cukup luas kepada masyarakat pemilih dalam menentukan pilihannya.

Dalam amar putusannya, majelis hakim menyatakan:

a. Mengabulkan permohonan para Pemohon.

b. Menyatakan Penjelasan Pasal 59 Ayat (1) Undang-Undang Nomor 32 Tahun 2004 tentang Pemerintahan Daerah, bertentangan dengan UUD Negara Republik Indonesia Tahun 1945.

c. Menyatakan Penjelasan Pasal 59 Ayat (1) Undang-Undang Nomor 32 Tahun 2004 tentang Pemerintahan Daerah tersebut, tidak mempunyai kekuatan hukum mengikat.

d. Memerintahkan agar putusan ini dimuat dalam Berita Negara dalam jangka waktu paling lambat 30 hari. 
Dengan adanya putusan MK tersebut, berarti parpol atau gabungan parpol yang boleh mengajukan calon kepala daerah tidak hanya mereka yang mempunyai kursi di DPRD. Namun bisa merupakan gabungan parpol yang akumulasi suaranya lebih dari $15 \%$ dalam pemilihan anggota DPRD 2004 lalu. Putusan MK ini jelas-jelas tidak memberikan perlakuan yang sama serta sederajat terhadap sesama partai politik, karena dibedakan antara partai politik yang memiliki kursi di DPRD dan yang tidak memiliki kursi di DPRD.

Menurut Suharizal, ${ }^{9}$ putusan MK Nomor 005/PUU-III/2005 tanggal 25 Maret 2005 masih menyisakan beberapa persoalan hukum. Mengapa MK hanya membuka peluang kepada partai politik yang memperoleh suara, bagaimana halnya dengan partai politik yang berada dalam sebuah daerah pemilihan pada pemilu legislatif, tidak memperoleh suara atau bahkan tidak memiliki basis massa dan perwakilan daerahnya. Semestinya, bila MK konsisten terhadap peran konstitusional yang menjadi kewenangan MK, semua partai politik (baik yang memperoleh suara atau tidak, atau yang punya perwakilan atau tidak) yang dinyatakan sah mengikuti pemilu legislatif dan Pemilu Presiden dan Wakil Presiden diberikan kesempatan untuk mengajukan calon Kepala Daerah.

Berdasarkan uraian di atas, mengenai penerapan $v$ threshold di dalam sistem pilkada di Indonesia seharusnya menjadi permasalahan yang harus di carikan solusi karena hal ini dapat membatasi hak-hak partai politik untuk ikut berkompetisi di pilkada. Namun kenyataannya penerapan parliamentary threshold masih tetap eksis di dalam Undang-Undang Nomor 10 Tahun 2016 tentang Pilkada, sebagaimana termaktub di dalam Pasal 40 Ayat (1) yang menyatakan bahwa "Partai Politik atau gabungan partai politik dapat mendaftarkan pasangan calon jika telah memenuhi persyaratan perolehan paling sedikit $20 \%$ dari jumlah kursi Dewan Perwakilan Rakyat Daerah atau 25\% dari akumulasi perolehan suara sah dalam pemilihan umum anggota Dewan Perwakilan Rakyat Daerah di daerah yang bersangkutan". Pelaksanaan pasal ini merupakan salah satu faktor penghambat terwujudnya demokrasi dan jelas hal ini bertentangan dengan Undang-Undang Nomor 2 Tahun 2011 tentang Partai Politik, di dalam Pasal 12 huruf a, yang menyatakan bahwa, "Partai Politik berhak memperoleh perlakuan yang sama, sederajat, dan adil dari negara".

Pertentangan kedua peraturan perundangan-undangan ini dapat memberikan kekacauan bagi sistem hukum di Indonesia. Hal ini juga telah mencederai keadilan yang didambakan oleh masyarakat dan dilindungi oleh UUD 1945 sebagaimana yang termaktub di dalam Pasal 27 Ayat (1) "segala warga negara bersamaan kedudukannya di dalam hukum dan pemerintahan dan wajib menjunjung hukum dan pemerintahan itu dengan tidak ada kecualinya".

\section{Dinamika Hubungan Kerja Antara DPRD Dan Calon Kepala Daerah Dari Perseorangan Yang Tidak Mampu Mewujudkan Prinsip Check And Ballances}

\footnotetext{
${ }^{9}$ Suharizal, Opcit, hlm, 64-65.
} 
Menurut Undang-Undang Nomor 10 Tahun 2016 tentang Pilkada, di dalam Pasal 41 Ayat (1) dan Ayat (2) menyatakan bahwa pasangan calon perseorangan dapat mendaftarkan diri sebagai calon kepala daerah jika memenuhi syarat dukungan. Ketentuan Pasal 41 ini merupakan wujud nyata dari pelaksanaan Pasal 27 Ayat (1) UUD 1945. Ketentuan Pasal ini merupakan terobosan baru berkenaan dengan calon kepala daerah dari perseorangan.

Mekanisme pilkada yang membuka peluang bagi pasangan calon kepala daerah dari perseorangan untuk dapat mengikuti pilkada langsung merupakan pelaksanaan keinginan masyarakat yang dewasa ini semakin tidak percaya pada kinerja partai politik. Dengan membuka peluang bagi calon perseorangan, diharapkan akan ditemukan calon pemimpin yang benar-benar memperhatikan kepentingan masyarakat, karena calon perseorangan merupakan individu yang didukung oleh sejumlah orang. Calon perseorangan bukanlah calon yang berasal dari partai politik atau gabungan partai politik. Namun untuk menjadi calon kepala daerah melalui mekanisme calon perseorangan tidaklah mudah. Persyaratan yang harus dipenuhi oleh calon perseorangan termaktub di dalam ketentuan Pasal 41 Ayat (1) dan Ayat (2).

Beratnya persyaratan yang harus dipenuhi oleh calon perseorangan untuk dapat mengikuti pilkada menegaskan bahwa Undang-Undang Nomor 10 Tahun 2016 tentang Pilkada, sepertinya ingin tetap memprioritaskan pasangan calon kepala daerah yang berasal dari partai politik atau gabungan partai politik. Hal tersebut bertujuan untuk menjaga kelangsungan sistem pemerintahan suatu negara. Sebagaimana yang dijelaskan oleh seorang ilmuan politik Amerika Serikat, Clinton Rossiter menekankan bahwa partai politik memegang peranan penting dalam mendukung demokrasi disuatu negara, ia menulis bahwa "Tidak ada Amerika tanpa demokrasi, tidak ada demokrasi tanpa politik, tidak ada politik tanpa partai, serta tidak ada partai tanpa kompromi dan moderasi”. Hal senada juga diungkapkan oleh Kolumnis Fareed Zakaria, "Tanpa keberadaan partai politik, kehidupan politik di suatu negara terjerembab hanya menjadi permainan sekelompok individu atau permainan orang kuat tertentu". 10

Keberadaan partai politik merupakan salah satu ciri pada suatu negara demokrasi, selain ciri yang lainnya yaitu pemilihan umum yang langsung, umum, bebas, rahasia, jujur dan adil. Melalui partai politik aspirasi rakyat diformulasikan secara sistematis dan diartikulasikan untuk menjadi keputusan-keputusan politik yang mempengaruhi penyelenggaraan negara atau kebijakan publik lainnya. Kinerja utama partai politik diwujudkan melalui mekanisme di parlemen, antara lain, menyusun undang-undang, menyusun anggaran pendapatan dan belanja, serta mengawasi jalannya pemerintahan.

Berkenaan dengan hubungan kerja antara DPRD dengan kepala daerah menurut UndangUndang Nomor 9 Tahun 2015 tentang Pemerintahan Daerah, di dalam Pasal 207 Ayat (1) bahwa "Hubungan kerja antara DPRD dan kepala daerah didasarkan atas kemitraan yang

${ }^{10}$ Lihat, https://rukantokas.wordpress.com/2011/10/29/menaruh-harapan-pada-partai-politik/, Diakses pada Minggu, 31 Mei pukul, 00.32 WIB. 
sejajar". Maksud dari "hubungan kemitraan" menurut Ayat (2) dijelaskan bentuk-bentuknya, sebagai berikut:

a. Persetujuan bersama dalam pembentukan Perda;

b. Penyampaian laporan keterangan pertanggung jawaban kepada DPRD;

c. Persetujuan terhadap kerja sama yang akan dilakukan Pemerintah Daerah;

d. Rapat konsultasi DPRD dengan kepala daerah secara berkala; dan

e. Bentuk lainnya sesuai dengan ketentuan peraturan perundang-undangan.

Berdasarkan penjelasan di atas hubungan antara DPRD dan kepala daerah saling terkait dalam menjalankan fungsi penyelenggaraan pemerintahan. Jika dihubungkan dengan ketetentuan Pasal 41 Ayat (1) dan Ayat (2) UU Pilkada, yang membuka kesempatan bagi calon perseorangan untuk ikut dalam pilkada, akankah dapat memberikan kontribusinya bagi daerah yang akan dipimpinnya tersebut.

Calon perseorangan yang bukan dari partai politik atau gabungan partai politik kenyataannya dalam menjalankan pemerintahan tidak akan memiliki kekuatan dalam parlemen karena pada dasarnya unsur-unsur dari internal parlemen itu ditempati oleh orangorang yang berasal dari partai politik atau gabungan partai politik. Hal inilah yang nantinya akan menimbulkan ketidakseimbangan hubungan antara kepala daerah dengan DPRD, artinya legitimasi kepala daerah yang berasal dari calon perseorangan akan melemah dihadapan DPRD yang merupakan kalangan-kalangan yang berasal dari partai politik.

Seperti contoh kasus yang terjadi disejumlah tempat, pasangan calon yang memenangkan pilkada adalah mereka yang berasal dari calon perseorangan atau yang dicalonkan oleh gabungan partai-partai politik kecil yang memiliki kursi di DPRD maupun yang tidak. Pasangan calon ini telah memenangkan pilkada dengan mengalahkan pasangan calon lain yang didukung oleh parpol-parpol besar yang memiliki kursi di DPRD. Namun faktanya dalam praktik hubungan kerja antara eksekutif dan legislatif daerah tersebut, akhirnya terjadi ketidakseimbangan hubungan atau distorsi politik antara kedua lembaga tersebut yang berujung pada konflik atau mandeknya kegiatan pemerintahan. Seperti yang terjadi di Banyuwangi, Depok, dan sejumlah daerah lainnya, terus-menerus meradang karena tidak kuatnya basis politik yang dimiliki eksekutif untuk mengendalikan situasi politik meskipun telah dipilih rakyat dengan suara terbanyak. ${ }^{11}$

Fenomena pasca pilkada di Kabupaten Banyuwangi menarik dibahas terkait dengan keberadaan pasangan Bupati (Ratna Ani Lestari) dan Wakil Bupati (Yusuf Noer Iskandar) yang diusung oleh koalisi partai-partai kecil yang menang dalam pilkada, namun mengalami guncangan politik yang luar biasa sehingga pemerintahan daerah tidak mampu berjalan secara efektif. Perjalanan pemerintahan pasangan Bupati dan Wakil Bupati Banyuwangi tersebut selama beberapa tahun tampak cenderung mengalami guncangan politik dari berbagai elemen parpol, LSM, dan masyarakat. Oleh karena itu, Ketua DPRD Banyuwangi Ahmad Wahyudi menyatakan setuju dan segera mengambil jalan tengah untuk menyelesaikan polemik

\footnotetext{
${ }^{11}$ Suharizal, Opcit. Pemilukada ..., hlm, 152.
} 
Banyuwangi, salah satunya dengan membuat sebuah kesepakatan antara pihak yang berkepentingan dan pemenang pilkada, untuk menemukan jalan tengah. ${ }^{12}$

Namun reaksi elemen-elemen politik dan masyarakat terhadap pasangan Bupati dan Wakil Bupati Banyuwangi dari tahun ke tahun pun terus menguat. Desakan tuntutan mundur terhadap pasangan kepala daerah Banyuwangi ini juga terus bermunculan. Demontrasi tidak hanya datang dari kalangan masyarakat, namun juga dari lingkungan birokrasi. Belasan ribu PNS di seluruh Kabupaten Banyuwangi melakukan mogok kerja mulai 22 Januari 2006.

Contoh kasus di atas dapat mengambarkan dinamika tentang betapa berpengaruhnya hubungan antara DPRD dan kepala daerah dalam penyelenggaraan pemerintahan. Sikap politik DPRD yang tidak memberikan dukungan politik kepada kepala daerah menjadikan posisi kepala daerah menjadi lemah.

\section{PENUTUP}

Berdasarkan pembahasan masalah di atas, dapat disimpulkan bahwa yang menjadi alasan bahwa penerpan parliamentary threshold sebagaimana termaktub di dalam ketentuan Pasal 40 Ayat (1) Undang-Undang Nomor 10 Tahun 2016 tentang Pemilihan Gubernur, Bupati dan Walikota, dapat menghambat pelaksanaan demokrasi karena bertentangan dengan peraturan perundang-undangan yaitu Undang-Un Undang-Undang Nomor 2 Tahun 2011 tentang Partai Politik, Pasal 12 huruf a. Hal ini juga telah mencederai keadilan yang didambakan oleh masyarakat dan dilindungi oleh UUD 1945 sebagaimana yang termaktub di dalam Pasal 27 Ayat (1) UUD 1945.

Berkenaan dengan dinamika hubungan kerja antara DPRD dan calon kepala daerah dari perseorangan yang seharusnya menjadi hubungan kemitraan sejajar dalam melaksanakan fungsi penyelenggaraan pemerintahan daerah, akan sulit tercapai. Permasalahan ini muncul karena kepala daerah dari perseorangan nyatanya tidak akan memiliki power di parlemen sehingga hal itu akan berdampak pada sikap politik DPRD yang tidak memberikan dukungan politik kepada kepala daerah tersebut. Alasan inilah yang akan menjadikan posisi kepala daerah menjadi lemah, sehingga berpengaruh kepada tidak terwujudnya prinsip check and balances di dalam menjalankan fungsi pemerintahan.

\section{DAFTAR PUSTAKA \\ Buku}

Hery Susanto dkk, Menggapai Demokrasi (Jejak Syaukani HR, Konflik Politik dan Memenangi Pilkada), Penerbit Republika, Jakarta, 2005

I Gde Pantja Astawa, Problematika Hukum Otonomi Daerah di Indonesia, Alumni, Bandung, 2008

\footnotetext{
${ }^{12}$ Bali Post, 3 September 2005.
} 
Jimly Asshiddiqie, Konsolidasi Naskah UUD 1945 Setelah Perubahan Keempat, Pusat Studi Hukum Tata Negara UI, 2002

S.H. Sarundajang, Pilkada Langsung, Problema dan Prospek, Katahasta Pustaka, 2005

Suharizal, Gagasan Pemilihan Kepala Daerah Langsung, dalam Reformasi Hukum, Fakultas Hukum Universitas Andalas, Padang, 2003

Suharizal, Pemilukada (Regulasi, Dinamika, dan Konsep Mendatang), PT Raja Grafindo Persada, Jakarta, 2012

\section{Surat Kabar}

Bali Post, 3 September 2005.

\section{Peraturan Perundang-undangan}

Undang-Undang Dasar Negara Republik Indonesia Tahun 1945.

Undang Nomor 2 Tahun 2008 jo Undang-Undang Nomor 2 Tahun 2011 tentang Partai Politik.

Undang-Undang Nomor 10 Tahun 2016 tentang Pemilihan Gubernur, Bupati, dan Walikota Menjadi Undang-Undang.

Undang-Undang Nomor 23 Tahun 2014 tentang Pemerintahan Daerah.

Putusan Mahkamah Konstitusi Perkara Nomor 005/PUU-III/2005 tanggal 22 Maret 2005. 